\title{
MECHANICAL PROPERTIES OF TAMARINDUS INDICA
}

\author{
Mohd-Jamil AW*, Zairul AR, Suffian M \& Mohd-Fahmi A \\ Forest Research Institute Malaysia, 52109 Kepong, Selangor, Malaysia \\ *mohdjamil@frim.gov.my
}

Submitted February 2019; accepted July 2019

\begin{abstract}
The timber of ramin and rubberwood are highly valued for furniture, panelling and decorative mouldings. With the trade restriction of ramin and escalated market price of rubberwood, the widely distributed Tamarindus indica is a potential alternative for light-coloured timber. The tamarind tree was introduced to Malaysia for food and medicinal uses. This article reports on some physical and mechanical properties of T. indica timber. Timber specimens of a 15-year-old T. indica were tested for modulus of rupture (MOR), modulus of elasticity (MOE), compressive strength parallel to the grain, compressive strength perpendicular to the grain, shearing strength, Janka hardness and specific gravity according to BS 373 standard methods. The sapwood of T. indica is pale yellow to cream in colour and the heartwood is poorly distinguished. Planing of the timber produced good to excellent surfaces and was rated as easy. The green and air-dry MOR values were 79.9 and $95.3 \mathrm{~N} \mathrm{~mm}^{-2}$ respectively. The green and air-dry MOE values were $8530 \mathrm{~N} \mathrm{~mm}^{-2}$ and $8476 \mathrm{~N} \mathrm{~mm}^{-2}$ respectively. Janka hardness of T. indica was $4747 \mathrm{~N}$, indicating a potential usage for high foot-traffic flooring such as for offices, showrooms, indoor sport arenas and restaurants. The specific gravity values were recorded in the range of 0.637 to 0.724 .
\end{abstract}

Keywords: Alternative species, timber strength, specific gravity, light-coloured

\section{INTRODUCTION}

Light-coloured timbers are often sought for furniture, panelling and decorative mouldings. Timbers such as ramin (Gonystylus spp.) has established a reputation as first class joinery and framing material (Wong 2002). Ramin retains very significant commercial value despite the fact that it is categorised as light hardwood with moderate strength properties and low resistance against biological deterioration. The sapwood is lighter in colour and is poorly distinguished from the heartwood, which is white to creamy yellow. The air-dry density of ramin ranged from 530 to $785 \mathrm{~kg} \mathrm{~m}^{-3}$. However, over-exploitation has led to all species of ramin being listed as endangered. Internationally, the market for ramin has been restricted by the Convention on International Trade in Endangered Species of Wild Fauna and Flora (CITES) under the Appendix 2 for the future survival of the species in the wild (MohdJamil 2018).

With the trade restriction on ramin, we are forced to seek alternative sources of lightcoloured timber especially since rubberwood (Hevea brasiliensis) is no more a bargain material. Rubberwood (air-dry density of 560 to
$640 \mathrm{~kg} \mathrm{~m}^{-3}$ ) has become a niche for furniture and fittings and fetches high prices. Mahang (Macaranga spp.) is found in abundance in logged-over forests and has been claimed to be the most potential substitute for ramin (Killmann 1990). Similar to ramin, the sapwood of mahang is not easily differentiated from its heartwood, which is light yellow-brown, occasionally with a pink tinge. However, the density of mahang is excessively lower than ramin or rubberwood and its specific gravity ranged from 0.240 to 0.442. Low-density timbers usually produce fuzzy grain, which eventually leads to substandard material and unsatisfactory impression of the finished products. A similar issue was observed in machining of sentang (Azadirachta excelsa) and khaya (Khaya ivorensis).

This study investigated some physical and mechanistic properties of Tamarindus indica as alternative for light-coloured timber. The tree of T. indica (locally known as asam jawa) is a moderate to large exotic species with a potential to grow up to $24 \mathrm{~m}$ in height and over $1 \mathrm{~m}$ in diameter. The species was introduced to Malaysia in the distant past for various food and medicinal 
uses. Today, the trees of $T$. indica are widely found throughout the country. In Africa and India, the timber is highly valued for furniture, panelling, wheels, axles, gears for mills, ploughs, planking for sides of boats, wells, mallets, knife and tool handles, rice pounders, mortars and pestles (Bhadoriya et al. 2011).

\section{MATERIALS AND METHODS}

An extra assessment of T. indica was conducted in which the test material was obtained from one tree (Mohd-Jamil 2017). The tree was planted in 2003 for landscaping in a housing area located in Serendah, Selangor. The age of the tree was approximately 15 years old. A log of $1.5 \mathrm{~m}$ long was cut at $50 \mathrm{~cm}$ from above the ground. The bottom and top diameters measured 22.3 and $20.5 \mathrm{~cm}$ respectively.

\section{Specimen preparation}

The $\log$ of $T$. indica was sawn into sticks of $30 \mathrm{~mm} \times 30 \mathrm{~mm}$ and one stick of $60 \mathrm{~mm} \times$ $60 \mathrm{~mm}$ at the Log Processing Workshop of Forest Research Institute Malaysia (FRIM). Half of the sticks were subsequently processed into specimen sizes at the FRIM Machining and Prototyping Workshop for green condition tests. The other half was stacked and air-dried under shed until constant weight was attained before being processed into specimen sizes for air-dry condition tests. The sticks were cut and planed into specimen sizes for static bending, compression parallel to grain, compression perpendicular to grain, shear, Janka hardness and specific gravity tests. The mechanical tests were conducted based on BS 373 (BSI 1957) standard methods for $2 \mathrm{~cm}$ specimens using a universal testing machine at the FRIM Wood Composite Testing Laboratory.

\section{Static bending test}

The nominal size of the specimen was $20 \mathrm{~mm}$ $\times 20 \mathrm{~mm} \times 300 \mathrm{~mm}$. Force was applied based on three-point loading method with a span of $280 \mathrm{~mm}$. A constant loading speed was applied at $6.6 \mathrm{~mm} \mathrm{~min}^{-1}$. The test arrangement is shown in Figure 1. Modulus of elasticity (MOE) and modulus of rupture (MOR) were calculated using the formulae:

$$
\begin{aligned}
& \mathrm{MOE}=\frac{1}{4} \frac{\Delta \mathrm{F}}{\Delta 1} \frac{\mathrm{s}^{3}}{\mathrm{bd}^{3}} \\
& \mathrm{MOE}=\frac{3}{2} \frac{\mathrm{F}_{\mathrm{bend}} \mathrm{s}}{\mathrm{bd}^{2}}
\end{aligned}
$$

where, $\frac{\Delta \mathrm{F}}{\Delta 1}$ is the slope of the graph $\left(\mathrm{N} \mathrm{mm}^{-1}\right)$, $\mathrm{s}$ is the bending span $(\mathrm{mm}), \mathrm{b}$ is the width of the specimen $(\mathrm{mm}), \mathrm{d}$ is the thickness of the specimen $(\mathrm{mm})$ and $\mathrm{F}_{\text {bend }}$ is the maximum bending load $(\mathrm{N})$.

\section{Compression parallel to grain test}

The nominal size of the specimen was $20 \mathrm{~mm}$ $\times 20 \mathrm{~mm} \times 60 \mathrm{~mm}$. Force was applied parallel to the grain. A constant loading speed was applied at $0.6 \mathrm{~mm} \mathrm{~min}^{-1}$. The test arrangement is shown in Figure 2. Compressive strength parallel to the grain $\left(\sigma_{\text {comp,ll }}\right)$ was calculated using the formula:

$$
\sigma_{\text {comp,ll }}=\frac{\mathrm{F}_{\text {comp,ll }}}{\mathrm{A}}
$$

where, $\mathrm{F}_{\text {comp,ll }}$ is the maximum compressive load $(\mathrm{N})$ parallel to the grain and A is the crosssectional area normal to the direction of load $\left(\mathrm{mm}^{2}\right)$.

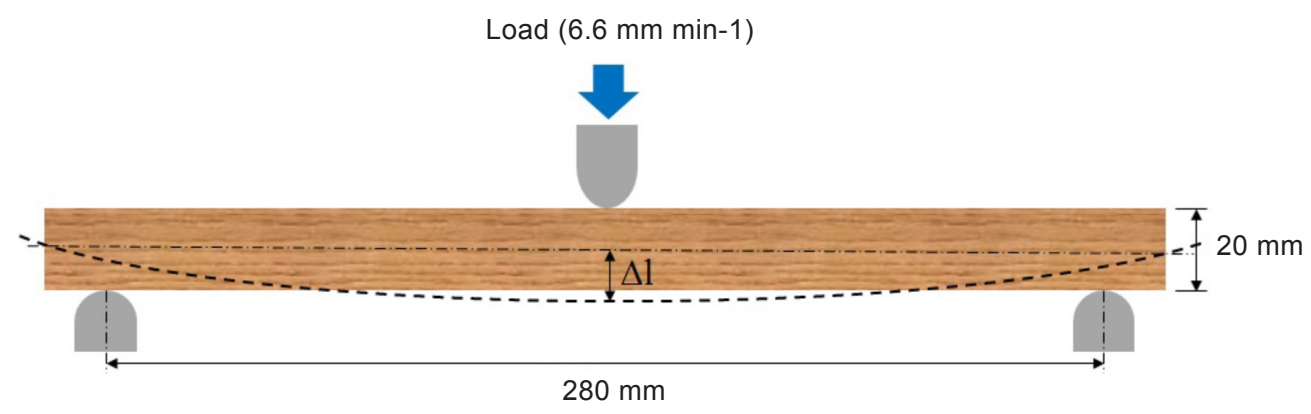

Figure 1 Arrangement for static bending test 


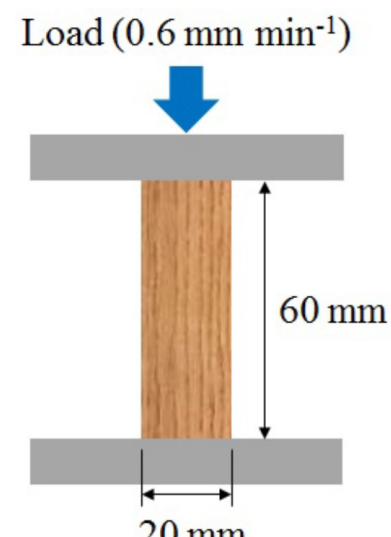

$20 \mathrm{~mm}$

Figure 2 Arrangement for compression parallel to grain test

\section{Compression perpendicular to grain test}

The nominal size of the specimen was $50 \mathrm{~mm} \times 50 \mathrm{~mm} \times 50 \mathrm{~mm}$. Force was applied perpendicular to the grain. A constant loading speed was applied at $0.6 \mathrm{~mm} \mathrm{~min}^{-1}$. The test arrangement is shown in Figure 3. Compressive strength perpendicular to the grain $\left(\sigma_{\text {comp,L }}\right)$ was calculated using the formula:

$$
\sigma_{\text {comp }, \mathrm{L}}=\frac{\mathrm{F}_{\text {comp@2.54 mm }}}{\mathrm{A}}
$$

where, $\mathrm{F}_{\text {comp@2.54 mm }}$ is the compressive load (N) perpendicular to the grain at $2.54 \mathrm{~mm}$ compression distance and $\mathrm{A}$ is the cross-sectional area normal to the direction of load $\left(\mathrm{mm}^{2}\right)$.

\section{Shear parallel to grain test}

The nominal size of the specimen was $20 \mathrm{~mm} \times$ $20 \mathrm{~mm} \times 20 \mathrm{~mm}$. Force was applied with the plane of shearing parallel to the grain. A constant loading speed was applied at $0.6 \mathrm{~mm} \mathrm{~min}^{-1}$. The test arrangement is shown in Figure 4. Shear strength parallel to the grain $\left(\sigma_{\text {shear }}\right)$ was calculated using the formula:

$$
\sigma_{\text {shear }}=\frac{F_{\text {shear }}}{A}
$$

where, $\mathrm{F}_{\text {shear }}$ is the maximum shearing load $(\mathrm{N})$ parallel to the grain and $\mathrm{A}$ is the area of shear $\left(\mathrm{mm}^{2}\right)$.

\section{Janka hardness test}

The test was conducted using the specimens of static bending test. A constant force of

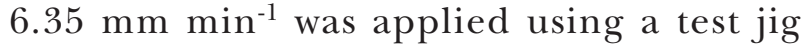
with a semi-circular-end steel bar of $11.28 \mathrm{~mm}$ in diameter. The test arrangement is shown in Figure 5. The load corresponding to the penetration depth of $5.64 \mathrm{~mm}$ was recorded as the Janka hardness value.

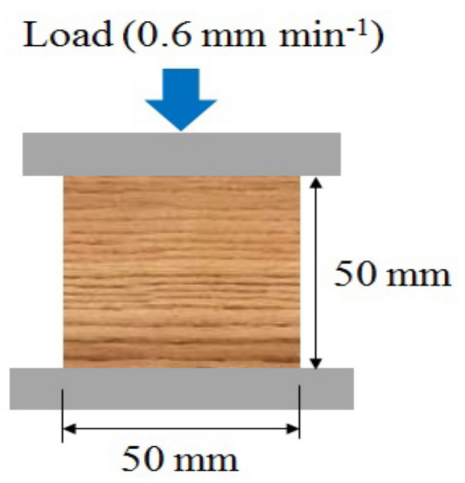

Figure 3 Arrangement for compression perpendicular to grain test

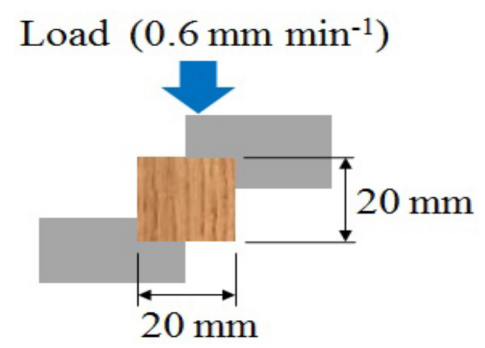

Figure 4 Arrangement for shear parallel to grain test

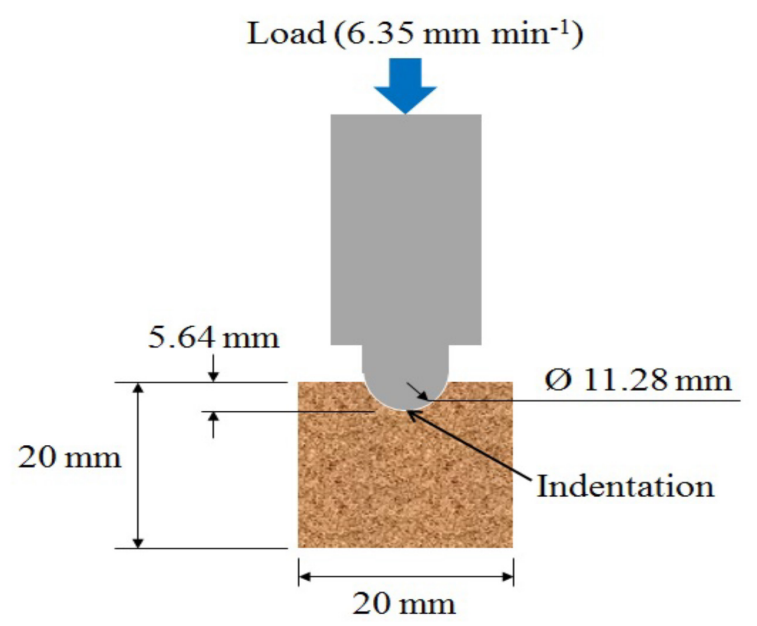

Figure 5 Arrangement for Janka hardness test 


\section{Determination of density and specific gravity}

The nominal size of the specimen was $20 \mathrm{~mm} \times$ $20 \mathrm{~mm} \times 60 \mathrm{~mm}$. The density $(\rho)$ and specific gravity $(\mathrm{SG})$ was calculated using the formulae:

$$
\begin{aligned}
& \rho=\frac{\mathrm{m}}{\mathrm{v}} \\
& \mathrm{SG}=\frac{\mathrm{m}_{\text {od }}}{\mathrm{v}} \frac{1}{\rho_{\mathrm{H} 2 \mathrm{O}}}
\end{aligned}
$$

where, $\mathrm{m}$ is the mass of the specimen at test $(\mathrm{kg})$, $\mathrm{V}$ is the volume of the specimen at test $\left(\mathrm{m}^{3}\right), \mathrm{m}_{\text {od }}$ is the oven-dry mass of the specimen $(\mathrm{kg})$, and $\rho_{\mathrm{H} 2 \mathrm{O}}$ is the density of water $\left(\mathrm{kg} \mathrm{m}^{-3}\right)$.

\section{RESULTS AND DISCUSSION}

The sapwood colour of T. indica is pale yellow to cream but more whitish compared with ramin or rubberwood. The colour texture of T. indica somewhat resembles sesendok (Endospermum spp.) with a faint yellow tinge and noticeably distinguished from batai (Albizia spp.) and mahang (Figure 6). In the present sample, the heartwood was poorly distinguished. The sapwood of a mature T. indica is up to $200 \mathrm{~mm}$ wide and the heartwood is dark brown in colour, often mottled with black and, occasionally, with a purplish hue (Bolza \& Keating 1972). Discoloration caused by fungi is common in the sapwood. We observed several spots of blue stain on the air-dry samples due to untreated and improper seasoning.

Planing of air-dry T. indica produced good to excellent surfaces and was rated as easy. However minor tear-out was observed in a few regions. Tear-out is often the result of planing against the direction of the grain or due to the presence of interlocked grain (Davis 1962). Sanded T. indica had smooth surfaces, although minor torn grain effects due to planing were occasionally observed. However, the heartwood was reported to be very hard and extremely difficult to work with hand and machine tools, and extremely resistant to impregnation (Bolza \& Keating 1972). The timber did not produce any distinctive odour when freshly cut. Air-drying process of $60 \mathrm{~mm} \times$ $60 \mathrm{~mm}$ cross-sectional boards took 39 days to dry from 58.4 to $21.4 \%$ moisture content (Figure 7 ).

The mechanical test results of mean, standard deviations, minimum and maximum values of $T$. indica are summarised in Table 1. Green and air-

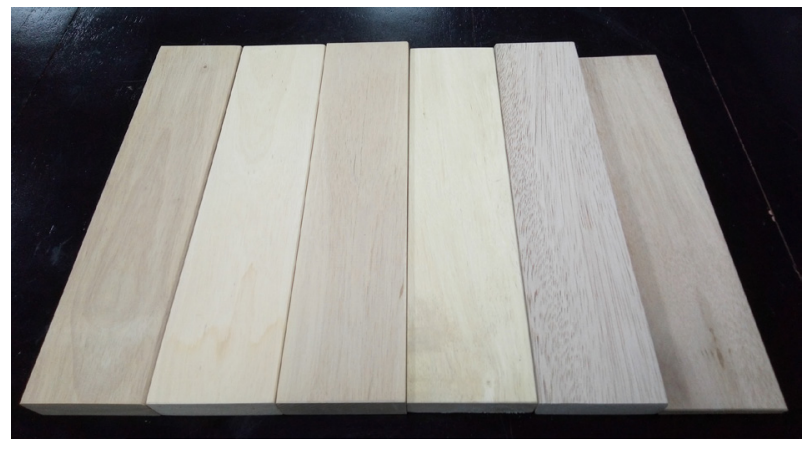

Figure 6 (Left to right) Timber boards of rubberwood, sesendok, ramin, asam jawa, batai and mahang

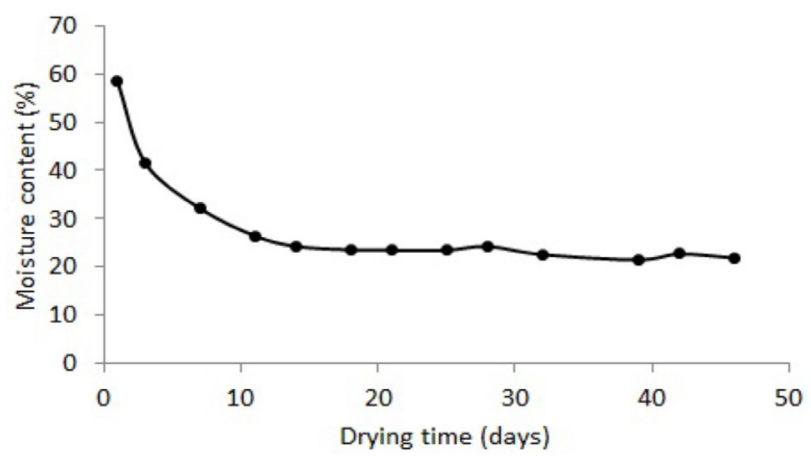

Figure 7 Air drying curve of Tamarindus indica of $60 \mathrm{~mm} \times 60 \mathrm{~mm}$ board

dry specimens were generally tested at 58.4 and $18.0 \%$ moisture content respectively. Density of T. indica timber is $850 \mathrm{~kg} \mathrm{~m}^{-3}$ in dry condition (Rao \& Sampathrajan 2001). Earlier records showed that the density ranged from 810 to $1140 \mathrm{~kg} \mathrm{~m}^{-3}$ in $12 \%$ moisture content (Bolza $\&$ Keating 1972). These data are in agreement with the present test results of 775 to $857 \mathrm{~kg} \mathrm{~m}^{-3}$ at $18.0 \%$ moisture content considering samples of a younger tree.

Mean MOR values in green and air-dry conditions were 79.9 and $95.3 \mathrm{~N} \mathrm{~mm}^{-2}$ respectively. Although these values are considered superior and comparable with medium hardwoods such as keruing (Dipterocarpus spp.) and mengkulang (Heritiera spp.), the timber is not recommended for structural applications due to uncertain durability against wood decaying agents. We suggest for an additional study on the decay rating of $T$. indica to analyse the biological resistance of the timber. Nevertheless, the MOR values demonstrated that $T$. indica is surpassingly fit for furniture, panelling, mouldings and framings. 


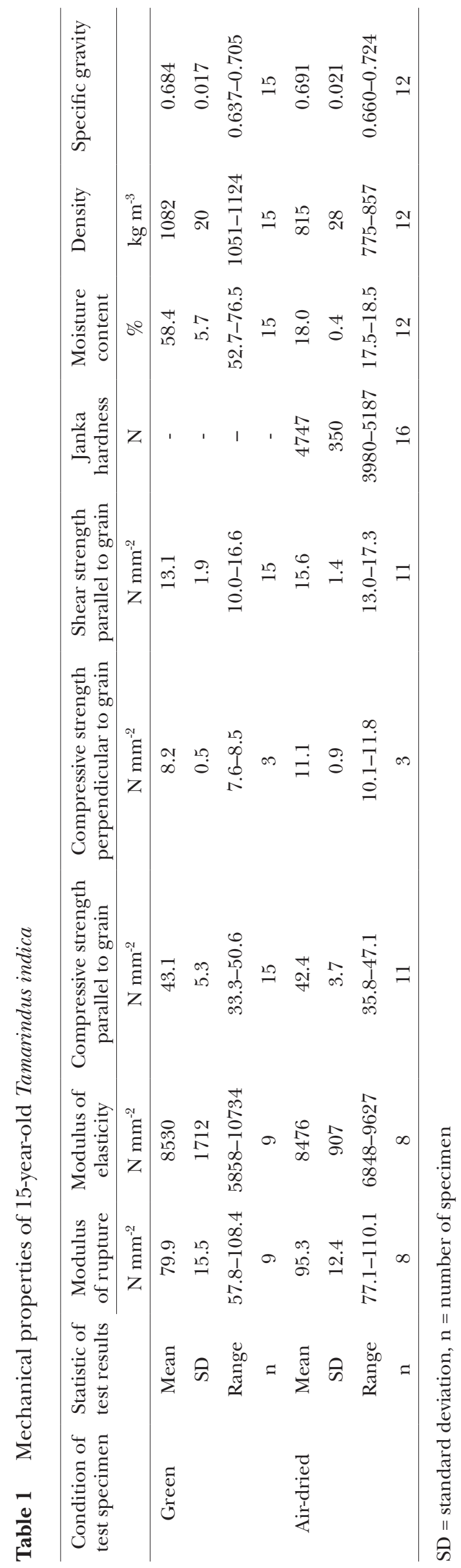


Air-dry samples had higher mechanical values compared with green samples except for $\mathrm{MOE}$ and compressive strength parallel to grain. Mean MOE values were 8530 and $8476 \mathrm{~N} \mathrm{~mm}^{-2}$ in green and air-dry conditions, while compressive strength parallel to grain values were 43.1 and $42.4 \mathrm{~N} \mathrm{~mm}^{-2}$ respectively. Similarly, opposite results as in this study have been observed in previous mechanical assessments of other Malaysian timbers. For example, green and air-dry test results of Janka hardness of petaling (Ochanostachys amentacea) are 6.59 and $6.36 \mathrm{kN}$ respectively, tualang (Koompassia excelsa) 8.23 and $7.21 \mathrm{kN}$ and penarahan (Myristica gigantean) 4.54 and $4.49 \mathrm{kN}$, regardless of timber density and type of test (Mohd-Jamil et al. 2018).

The compressive strength perpendicular to grain values in green and air-dry were $8.2 \mathrm{~N}$ and $11.1 \mathrm{~N} \mathrm{~mm}^{-2}$ respectively. These values are exceptionally high compared with most local timbers. The shearing strength parallel to grain in green and air-dry values were $13.1 \mathrm{~N}$ and $15.6 \mathrm{~N} \mathrm{~mm}^{-2}$ respectively. The values are comparable with ramin $\left(8.5 \mathrm{~N} \mathrm{~mm}^{-2}\right)$ and rubberwood $\left(11.0 \mathrm{~N} \mathrm{~mm}^{-2}\right)$ (Lee et al. 1993). The Janka hardness of T. indica was $4747 \mathrm{~N}$ which was fairly high for enduring indentation and scratches. It indicated that the timber is possibly suitable for high foot-traffic flooring such as for offices, showrooms, indoor sport arenas and restaurants (Mohd-Jamil 2016).

In a study of African timbers, Bolza and Keating (1972) reported that, at $12.0 \%$ moisture content, the timber of $T$. indica had MOR values of 114.0 to $134.0 \mathrm{~N} \mathrm{~mm}^{-2}$, MOE of 14,200 to $16,300 \mathrm{~N} \mathrm{~mm}^{-2}$, compressive strength parallel to grain of 62.0 to $71.0 \mathrm{~N} \mathrm{~mm}^{-2}$ and shear strength parallel to grain of 15.0 to $16.7 \mathrm{~N} \mathrm{~mm}^{-2}$. The mechanical properties of 15-year-old $T$. indica in this study were relatively higher than some light-coloured timber species of large mature trees. Batai (Paraserianthes falcataria) at $72.0 \%$ moisture content has an average MOR of $38 \mathrm{~N} \mathrm{~mm}^{-2}$, MOE of $6800 \mathrm{~N} \mathrm{~mm}^{-2}$, compressive strength parallel to grain of $19.2 \mathrm{~N} \mathrm{~mm}^{-2}$ and Janka hardness of 2360 N. Laran (Neolamarckia cadamba) at $17.8 \%$ moisture content has an average MOR of $50 \mathrm{~N} \mathrm{~mm}^{-2}$, MOE of $7700 \mathrm{~N} \mathrm{~mm}^{-2}$, compressive strength parallel to grain of $27.9 \mathrm{~N} \mathrm{~mm}^{-2}$ and Janka hardness of $1960 \mathrm{~N}$ (Lee et al. 1993). Batai and laran are two of the eight major species under the national plantation forestry programme.

Some of the above mentioned records were derived from slightly different testing procedures. For example, samples of small plantation trees were tested according to BS 373 methods of small clear specimen, whereas large mature trees were tested based on specimens of larger sizes (Mohd-Jamil 2017). Thus, a certain degree of deviation is expected in comparing data of different samples.

Since specific gravity is one of the key parameters in describing the properties of timber, the specific gravity of T. indica and some indigenous species are demonstrated in Table 2 . The specific gravity of T. indica is substantially

Table 2 Variation of specific gravity of indigenous light-coloured timbers in comparison with T. indica

\begin{tabular}{llc}
\hline Vernacular name & Botanical name & Specific gravity \\
\hline Asam jawa & Tamarindus indica & $0.64-0.72$ \\
Batai & Paraserianthes falcataria & $0.28-0.36$ \\
Jelutong & Dyera spp. & $0.27-0.41$ \\
Kasah & Pterygota horsfieldii & $0.44-0.52$ \\
Kembang semangkok & Scaphium spp. & $0.59-0.61$ \\
Laran & Neolamarckia spp. & $0.37-0.39$ \\
Minyak berok & Xanthophyllum spp. & $0.65-0.69$ \\
Perupok & Lophopetalum spp. & $0.50-0.51$ \\
Petai & Parkia spp. & $0.43-0.44$ \\
Pulai & Alstonia spp. & $0.34-0.35$ \\
Ramin & Gonystylus spp. & $0.58-0.59$ \\
Rubberwood & Hevea brasiliensis & $0.53-0.55$ \\
Sesenduk & Endospermum spp. & $0.33-0.40$ \\
Terap & Artocarpus spp. & $0.39-0.51$ \\
\hline
\end{tabular}


higher than other light-coloured timbers (Lee et al. 1993, Khairul et al. (2015) and Mohd-Jamil \& Khairul 2017). The value is $23 \%$ higher than ramin (Gonystylus spp.) which has established a reputation as a premium joinery timber on account of its colour and high density. The result was also comparable with minyak berok (Xanthophyllum spp.), a timber used for the manufacture of blockboards, panelling and flooring.

\section{CONGLUSIONS}

The sapwood of T. indica is pale yellow to cream in colour and the heartwood is poorly distinguished. Planing of the timber produced good to excellent surfaces and was rated as easy. Mechanical test results of $T$. indica demonstrated superior properties compared with some local lightcoloured timbers species. The green and air-dry MOR values of 15-year-old T. indica were 79.9 and $95.3 \mathrm{~N} \mathrm{~mm}^{-2}$ respectively. These values are comparable with some medium hardwood such as keruing and mengkulang. However, the timber of T. indica is not recommended for structural applications due to uncertain durability against wood decaying agents. The timber is more likely suitable for furniture manufacture, mouldings and framings. Based on relatively high Janka hardness value, the timber has potential for an exclusive light-coloured indoor flooring application.

\section{ACKNOWLEDGEMENTS}

Preparation of test specimens was assisted by personnel from the Log Processing Workshop and Machining and Prototyping Workshop, FRIM. Mechanical tests were supervised by Nordin P from Wood Composite Testing Laboratory. Farah HI and Najihah A assisted throughout the processing of log and mechanical testing.

\section{REFERENCES}

Bhadoriya SS, Ganeshpurkar A, Narwaria J, Rai G \& Jain AP. 2011. Tamarindus indica: extent of explored potential. Pharmacognosy Review 5: 73-81. doi: 10.4103/09737847.79102
Bolza E \& Keating WG. 1972. African Timbers: The Properties, Uses and Characteristics of 700 Species. Commonwealth Scientific and Industrial Research Organization, Melbourne.

BSI (British Standards Institution). 1957 (Reconfirmed 2018). BS 373. Methods of Testing Small Clear Specimens of Timber. BSI, London.

DAvIs EM. 1962. Machining and Related Characteristics of United States Hardwoods. Technical Bulletin No. 1267. United States Department of Agriculture, Washington.

Khairul M, Mohd Noor M, Izran K, Abdul Hamid S \& Yanti AK. 2015. New clone of sesenduk (FRIMsrp001). Journal of Tropical Resources and Sustainable Science 3: 135-138.

Killmann W. 1990. Research note on some physical and mechanical properties of Macaranga hosei. Journal of Tropical Forest Science 3: 193-194.

Lee YH, Engku ARC \& Chu YP. 1993. The Strength Properties of Some Malaysian Timbers. Timber Trade Leaflet No.34. Malaysian Timber Industry Board, Kuala Lumpur.

Mohd-Jamil AW. 2016. Janka Hardness Rating of Malaysian Timbers. Timber Technology Bulletin No. 58. Forest Research Institute Malaysia, Kepong.

MoHD-JAmiL AW. 2017. The Development of Strength Classification System of Malaysian Timbers: A Synopsis. FRIM Reports 106. Forest Research Institute Malaysia, Kepong.

Mohd-Jamil AW \& KhaIRul M. 2017. Variations of mechanical properties in plantation timbers of jelutong (Dyera costulata) and khaya (Khaya ivorensis) along the radial and vertical positions. Journal of Tropical Forest Science 29: 114-120.

Mohd-Jamil AW. 2018. Threatened Species Checklist of Commercial Timbers in Peninsular Malaysia. FRIM Technical Information No. 80. Forest Research Institute Malaysia, Kepong.

Mohd-Jamil AW, Noor Azrieda AR, Roszaini K, Ang LH \& Mohamad Fakhri I. 2018. Mechanical properties and durability of fast-growing timbers cultivated on degraded lands. Journal of Tropical Forest Science 30: 519-527. https://doi.org/10.26525/ jtfs2018.30.4.519527

Rao KS \& Sampathrajan A. 2001. Chemical characterization of selected dryland woody biomass tree species for energy production. Indian Journal of Dryland Agricultural Research and Development 16: 51-54.

Wong TM. 2002. A Dictionary of Malaysian Timbers. Second edition. Revised by Lim SC \& Chung RCK. Malayan Forest Records No. 30. Forest Department Peninsular Malaysia, Kuala Lumpur. 